J. Clin. Chem. Clin. Biochem.

Vol. 25, 1987, pp. 357-361

(C) 1987 Walter de Gruyter \& Co. Berlin - New York

\title{
Specific Creatinine Determination in Laboratory Animals Using the New Enzymatic Test Kit "Creatinine-PAP"
}

\author{
By $K$. Jung, C. Weßlau
}

Abteilung für Experimentelle Organtransplantation des Bereichs Medizin (Charité) der Humboldt-Universität zu Berlin

\section{F. Priem}

Institut für Pathologische und Klinische Biochemie des Bereichs Medizin (Charité) der Humboldt-Universität zu Berlin

\section{G. Schreiber}

Zentrallabor des Städtischen Krankenhauses Berlin-Friedrichshain and

A. Zubek

Zentrallabor des Städtischen Krankenhauses Berlin-Prenzlauer Berg

(Received December 12, 1986/February 26, 1987)

Summary: The new Creatinine-PAP test kit from Boehringer Mannheim GmbH was evaluated for the determination of creatinine in dogs, rabbits, guinea pigs, rats, and mice. In comparison with methods based on the reaction with alkaline picrate, the enzymatic method gave the lowest serum creatinine values. The differences are caused by serum substances (non-creatinine chromogens) reacting with picric acid. Noticeable differences between the standard inulin clearance and creatinine clearance (e.g., in rats) arise because the non-creatinine chromogens interfer differently in the picric acid methods, and serum and urine contain different concentrations of interfering substances. The concentrations of non-creatinine chromogens are different in the various laboratory animals. Since these substances cannot be entirely removed (e. g., in rats, dogs) by the adsorption procedure with Fuller's earth, we recommend the peroxidase-coupled enzymatic test as a practical and specific method for routine measurements of creatinine in laboratory animals.

\section{Introduction}

The determination of creatinine in body fluids based on the widely-used Jaffé reaction with alkaline picrate is subject to interference by many substances (1). The non-specificity of the Jaffé reaction has recently been claimed to be a serious problem of creatinine determinations in laboratory animals (2). For example, determination of serum creatinine in mice, using methods with picric acid, resulted in values that were five times higher than those obtained by the specific high performance liquid chromatography method (2). There is little doubt that such deviations from accu- racy are unacceptable. However, the application of high performance liquid chromatography is expensive, time-consuming and therefore not suited for the general use in laboratories working with experimental animals. Other approaches to a more specific assay for creatinine are founded on enzymatic procedures (3-5). Recently, a new test kit was introduced for determining creatinine in human body fluids (6). In the present study we have evaluated this method for the determination of creatinine in various laboratory animals, comparing its suitability with that of other generally used methods of creatinine determination. 


\section{Materials and Methods}

Animals and collection of samples

Male albino mice, rats, guinea pigs, and rabbits were delivered from VEB Versuchstierproduktion, Schönwalde, DDR. Mongrel dogs were from a local supplier.

Blood samples from mice, guinea pigs and rats were obtained after decapitation, and from rabbits and dogs by venepuncture. The samples were kept at room temperature and centrifuged at $4000 \mathrm{~g}$ at $4^{\circ} \mathrm{C}$ for $10 \mathrm{~min}$ within $30 \mathrm{~min}$. Serum was stored at $-20^{\circ} \mathrm{C}$ until analysis.

Urine samples were collected from rats (weighing 280 to $360 \mathrm{~g}$ ) placed in special restraining cages (7). When the rats were placed in these cages, the first collected sample was removed. The time between this and the next sample was measured and was considered as collection time (range between $12 \mathrm{~min}$ and $190 \mathrm{~min}$ ) for the calculation of creatinine clearance. Urine samples were weighed, centrifuged and stored like serum samples.

\section{Equipment}

In the manual methods for creatinine determination (method Nos. 1, 2, 3), all absorbance measurements were performed on a Beckman model DU-8 spectrophotometer (Beckman Instruments Inc., Fullerton, CA, USA). For pipetting in these methods we used Eppendorf pipettes (Eppendorf Gerätebau, Netheler \& Hinz, Hamburg, FRG). In method No. 4 a continuous-flow analyser from PGW Medingen, GDR, in method No. 5 the analyser ACP 5040 from Eppendorf Gerätebau and in method No. 6 the multichannel analyser Prisma (Clinicon, Bromma, Sweden) were used.

\section{Chemicals}

Creatinine was obtained from E. Merck, Darmstadt, FRG and dried over $\mathrm{P}_{2} \mathrm{O}_{5}$ to a constant weight. A standard solution was prepared in one laboratory and distributed to all others. This contained $100 \mu \mathrm{mol} / 1 \mathrm{creatinine}$ in $10 \mathrm{mmol} / \mathrm{l} \mathrm{HCl}$, and it was used for all methods except for the determinations of serum creatinine with method No. 6 , in which a protein-containing standard solution was used. Picric acid (Odczynniki Chemiczne, Gliwice, Poland) was purified by treatment with Darco G 60 (Serva Fine Chemicals, Heidelberg, FRG) and recrystallization. Fuller's earth was obtained from Serva. The peroxidase-coupled enzymatic creatinine reagent (Creatinine-PAP Test Combination, Cat. No. 839434) was supplied by Boehringer Mannheim $\mathrm{GmbH}$, Mannheim, FRG. Control materials were obtained from VEB Sächsische Serumwerke, Dresden, GDR.

\section{Methods}

The following procedures were used in this study:

\section{Method No. 1}

This method is based on the degradation of creatinine by creatininase and subsequent reactions catalysed by creatinase and sarcosine oxidase. The enzymatic reactions are coupled to a sensitive peroxidase indicator system. Guder et al. (6) summarized all these reactions in a formula pattern.

The method was performed according to the manufacturer's instructions with the exception of pipetting $12.5 \mu \mathrm{l}$ of sample and $250 \mu \mathrm{l}$ of reagent (6).

\section{Method No. 2}

This method eliminates the nonspecificity of the Jaffé reaction by removing the interfering substances by the adsorption of creatinine on Fuller's earth and its subsequent determination. The original method of Müller et al. (8) was used.

\section{Method No. 3}

This method is based on the deproteinisation of samples with picric acid and the determination of creatinine in the supernatant by the addition of $\mathrm{NaOH}$ solution. The assay was performed exactly as described in Arzneibuch (D. L.) DDR-'83 (9). To $250 \mu \mathrm{l}$ of sample, $1.5 \mathrm{ml}$ of picric acid were added, mixed and centrifuged for $10 \mathrm{~min}$ at $3000 \mathrm{~g}$. The supernatant was mixed with $50 \mu \mathrm{l}$ of $\mathrm{NaOH}$ solution (final concentrations: $41 \mathrm{mmol} / 1$ picric acid, $69 \mathrm{mmol} / \mathrm{l} \mathrm{NaOH}$ ) and the absorbance was measured between the 20th and 30 th min at $530 \mathrm{~nm}$.

\section{Method No. 4}

This method is a continuous-flow method (9) based on the autoanalyser principle. The final concentrations in the reaction mixture were $10 \mathrm{mmol} / 1$ picric acid and $176 \mathrm{mmol} / 1 \mathrm{NaOH}$. Absorbance was read at $510 \mathrm{~nm}$.

\section{Method No. 5 and Method No. 6}

Both methods are kinetic methods.

In method No. 5 (ACP 5040), $50 \mu$ of sample were mixed with $250 \mu \mathrm{l}$ of picric acid, then the reaction was started by the addition of $25 \mu \mathrm{l}$ of $\mathrm{NaOH} / \mathrm{Na}_{2} \mathrm{HPO}_{4}$-solution (final concentrations: $3.36 \mathrm{mmol} / \mathrm{l}$ picric acid, $120 \mathrm{mmol} / 1 \mathrm{NaOH}, 4.8 \mathrm{mmol} / 1$ $\mathrm{Na}_{2} \mathrm{HPO}_{4}$ ). The reaction was measured after $36 \mathrm{~s}$ at a cycle time of $12 \mathrm{~s}$ at $492 \mathrm{~nm}$ and $37^{\circ} \mathrm{C}$.

In method No. 6 (Prisma), $125 \mu$ l of sample and $800 \mu l$ of alkaline picrate solution (final concentrations: $17.7 \mathrm{mmol} / 1 \mathrm{pi}-$ cric acid, $143 \mathrm{mmol} / 1 \mathrm{NaOH}$ ) were mixed and the absorbance was measured at $492 \mathrm{~nm}$ and $27.5^{\circ} \mathrm{C}$ between the first and the third minute.

\section{Inulin clearance}

Clearance of creatinine was compared with the clearance of inulin in anaesthetized male rats. For that purpose, rats were anaesthetized by an intraperitoneal application of a mixture of sodium pentobarbital and ketamine at 45 and $30 \mathrm{mg} / \mathrm{kg}$ body weight, respectively. In order to maintain body temperature, rats were placed on a heated operating table maintained at $38^{\circ} \mathrm{C}$ by a rectal-controlled thermistor. A tracheotomy was performed. Both external jugular and the right iliac artery were cannulated for blood sampling, fluid infusion and blood pressure monitoring. Both ureters were cannulated for urine collecting. A priming dose of $10 \mathrm{mg}$ of inulin $(20 \mathrm{~g} / 1$ inulin dissolved in a solution consisting of $96 \mathrm{mmol} / 1 \mathrm{NaCl}$ and 170 $\mathrm{mmol} / \mathrm{l}$ mannitol) per $100 \mathrm{~g}$ of body weight was given, then a constant infusion of $3 \mathrm{ml} / \mathrm{h}$ was sustained. After an initial period of infusion of $45 \mathrm{~min}$ for equilibration, urine was collected during two 30 -min periods. Urine volumes were determined by weight. Blood samples were taken at the beginning and the end of each clearance period. As the serum concentration of inulin was relatively constant, the mean value was used to calculate the clearance. Inulin in serum and urine was measured according to Davidson \& Sackner (10).

\section{Statistical analyses}

Calculations were made using Student's t-test of paired and unpaired data.

\section{Results}

To characterize the methods applied in this study, we measured the between-day precision in two control materials with normal and elevated creatinine concentrations (60.6 and $227 \mu \mathrm{mol} / \mathrm{l}$ creatinine, respectively). 

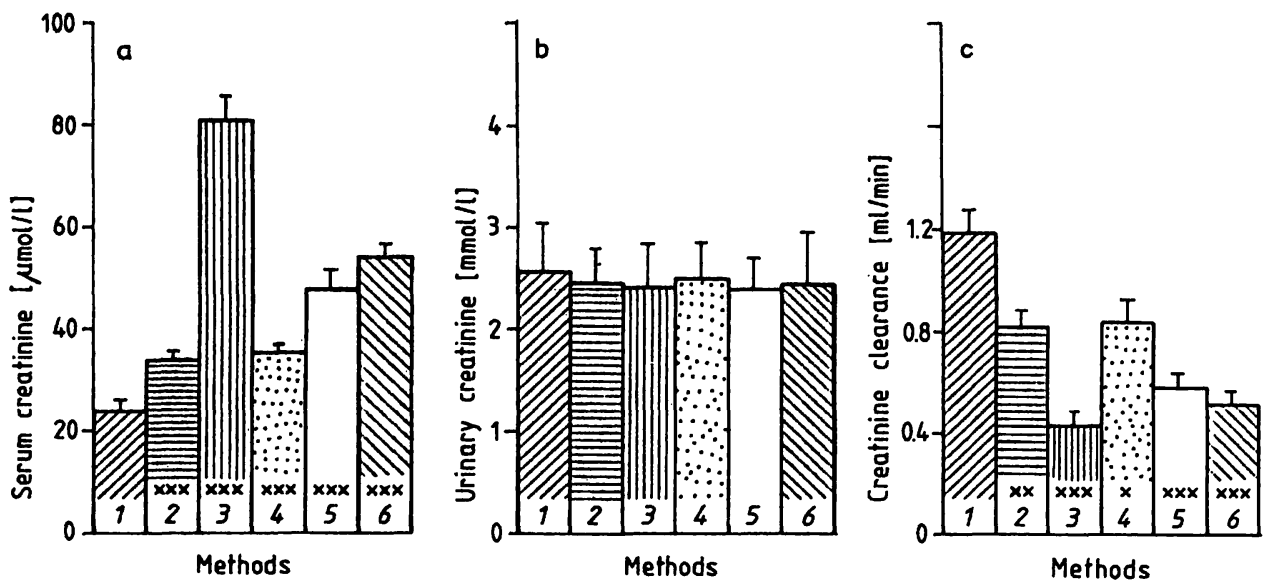

Fig. 1. Serum (a) and urine (b) creatinine in rats determined by different methods. Data represent arithmetic means \pm SEM $(n=21)$. Values of the enzymatic method (No. 1) were compared with the values obtained by the picric acid methods (No. 2: adsorption procedure with Fuller's earth; No. 3: direct picric acid method; No. 4: continuous llow method; No. 5: kinetic method with ACP; No. 6: kinetic method with Prisma). Following indices for statistically significant differences are used: $\times \mathrm{p}<0.05 ; \times \times \mathrm{p}<0.01 ; \times \times \times \mathrm{p}<0.001$.

Tab. 1. Comparison of inulin clearance and creatinine clearance in rats. Data are given as arithmetic means $\pm S D$, number of animals in parentheses.

\begin{tabular}{lll}
\hline Methods & \multicolumn{2}{l}{$\begin{array}{l}\text { Clearance }(\mathrm{ml} / \mathrm{min} \text { per } 100 \mathrm{~g} \\
\text { of body weight) }\end{array}$} \\
\cline { 2 - 3 } & $\begin{array}{l}\text { Rats, } \\
\text { anaesthetized }\end{array}$ & $\begin{array}{l}\text { Rats, placed } \\
\text { in restraining } \\
\text { cages } \\
(\mathrm{n}=21)\end{array}$ \\
& $(\mathrm{n}=12)$ & - \\
\hline Inulin clearance & $0.84 \pm 0.16$ & \\
Creatinine clearance & & $1.19 \pm 0.58^{\mathrm{a}}$ \\
1: Enzymatic & $1.15 \pm 0.38^{\mathrm{a}}$ & $0.82 \pm 0.35^{\mathrm{d}}$ \\
2: Adsorption & - & $0.43 \pm 0.23^{\mathrm{c}: \mathrm{e}}$ \\
3: Direct picric acid & - & $0.84 \pm 0.41^{\mathrm{d}}$ \\
4: Continuous flow & - & $0.58 \pm 0.26^{\mathrm{b}: \mathrm{e}}$ \\
5: Kinetic, ACP & - & $0.52 \pm 0.25^{\mathrm{c}: \mathrm{e}}$ \\
6: Kinetic, Prisma & - & \\
\hline
\end{tabular}

a.b.c : compared with inulin clearance, where a, $p<0.05$; $\mathrm{b}, \mathrm{p}<0.01 ; \mathrm{c}, \mathrm{p}<0.001$.

d.e: comparisons of creatinine clearance obtained with methods 2 to 6 with that obtained with method 1 , where d, $p<0.05$; e, p $<0.001$.
During the investigation period of 14 days, the coefficient of variation amounted to 2.5 to $7.9 \%$ for the "normal" control serum and 2.0 to $3.9 \%$ for the "abnormal" control serum. The results showed that all methods were performed with acceptable precision.

First, the enzymatic method was compared with the five picric acid techniques by determining creatinine in serum and urine from rats (figs. $1 \mathrm{a}$ and $1 \mathrm{~b}$ ) and by calculating the corresponding values of creatinine clearance (tab. 1). Whereas the methods based on picric acid gave creatinine concentrations in serum significantly higher than the enzymatic method (fig. 1a), the recorded urine concentrations were similar for all methods used (fig. 1b).

The creatinine clearance values determined with these 6 methods show enormous differences (tab. 1). The inulin clearance as a true measure of glomerular filtration rate was significantly lower than the creatinine clearance measured by the enzymatic method

Tab. 2. Comparison of methods for the determination of serum creatinine in various laboratory animals. Five to eight serum pools of the respective species were prepared and an aliquot was analysed by each method. Values of the enzymatic method (No. 1) were compared with the values obtained by the picric acid methods. Data represent arithmetic means $\pm \mathrm{SD}$.

Following indices for statistically significant differences are used:

$\mathrm{a}, \mathrm{p}<0.05 ; \mathrm{b}, \mathrm{p}<0.01 ; \mathrm{c}, \mathrm{p}<0.001$.

\begin{tabular}{lccrc}
\hline Method & \multicolumn{2}{c}{ Serum creatinine $(\mu \mathrm{mol} / \mathrm{l})$} & & \\
\cline { 2 - 5 } & Dogs & Rabbits & Guinea pigs & Mice \\
\hline 1: Enzymatic & $75 \pm 9.3$ & $103 \pm 7.9$ & $56 \pm 8.8$ & $19 \pm 5.8$ \\
2: Adsorption & $90 \pm 4.8^{\mathrm{b}}$ & $109 \pm 2.0$ & $61 \pm 1.4$ & $22 \pm 3.8$ \\
3: Direct picric acid & $1.08 \pm 3.2^{\mathrm{c}}$ & $148 \pm 3.1^{\mathrm{c}}$ & $113 \pm 1.5^{\mathrm{c}}$ & $67 \pm 1.0^{\mathrm{c}}$ \\
4: Continuous flow & $94 \pm 2.9^{\mathrm{c}}$ & $117 \pm 2.2^{\mathrm{c}}$ & $70 \pm 1.4^{\mathrm{b}}$ & $26 \pm 1.7^{\mathrm{a}}$ \\
5: Kinetic, ACP & $94 \pm 9.2^{\mathrm{b}}$ & $140 \pm 13^{\mathrm{c}}$ & $106 \pm 5.9^{\mathrm{c}}$ & $49 \pm 2.1^{\mathrm{c}}$ \\
6: Kinetic, Prisma & $92 \pm 3.4^{\mathrm{c}}$ & $122 \pm 2.9^{\mathrm{c}}$ & $95 \pm 2.9^{\mathrm{c}}$ & $70 \pm 1.0^{\mathrm{c}}$ \\
\hline
\end{tabular}


(tab. 1). The creatinine clearance of anaesthetized rats did not differ from that of rats placed in restraining cages (tab. 1). Thus, it must be concluded that creatinine clearance values lower than those for inulin clearance (methods $3,5,6$ ), and similar creatinine and inulin clearance values (methods 2,4 ) are both caused by varying degrees of interference by serum non-creatinine chromogens in the picric acid methods (tab. 1).

To determine whether the nonspecificity of the picric acid techniques was as important with other laboratory animals, serum creatinine was determined in dogs, rabbits, guinea pigs, and mice (tab. 2). The enzymatic method also gave the lowest values in all species. The direct picric acid method generally showed the highest creatinine concentrations.

In order to exclude the possibility of these differences being caused by the negative interference of other serum constituents on the peroxidase-coupled enzymatic reaction, we determined the recoveries of the methods. Aqueous $1 \mathrm{mmol} / \mathrm{l}$ creatinine solution or of redistilled water $(1 \mathrm{ml})$ were added to $9 \mathrm{ml}$ of rat serum. The following percentage recoveries $(\overline{\mathrm{x}} \pm \mathrm{SD}$; $\mathrm{n}=4$ ) were found:

method $1 \quad 101.8 \pm 0.8 \%$;

method $2 \quad 99.6 \pm 0.2 \%$;

method $3 \quad 89.3 \pm 3.2 \%$;

method $4 \quad 99.3 \pm 0.7 \%$;

method $5 \quad 92.0 \pm 1.2 \%$;

method $6 \quad 95.8 \pm 1.6 \%$.

These results prove that the peroxidase-coupled procedure is not subject to negative interference.

\section{Discussion}

Our results show that the newly introduced peroxidase-coupled enzymatic test combination "Creatinine-PAP" is a suitable test for precise determination of creatinine concentrations in body fluids of laboratory animals. They also confirm recent investigations (2) that other methods such as those based on picric acid (Jaffé reaction) have to be used to determine creatinine in laboratory animals. The overestimation of creatinine is especially marked in serum, whereas the determination in urine is less or not affected (2).

The apparent concentrations of creatinine determined in the serum of the species differ, depending on the version of Jaffé reaction used. These intermethod biases are caused by the differential effects of interfering substances on various methods and would explain the wide range of reference intervals of serum creatinine for the same species (11). After the pretreatment of serum samples with Fuller's earth the picric acid method showed similar serum creatinine values for mice, guinea pigs, and rabbits in comparison with the peroxidase-coupled test. However, both methods give different results in rats and dogs. This is possibly caused by the occurrence of compounds (e. g., keto acids) in the serum of these animals, which, in addition to creatinine, are adsorbed 'on Fuller's earth and interfere with the subsequent Jaffé reaction (1). Thus, the adsorption method is not always suited to give "true" creatinine values.

In general, negligible amounts of interfering noncreatinine chromogens are found in urine $(1,2,11)$. Although it is generally accepted that creatinine is secreted by the rat kidney, creatinine clearance determined by the direct picric acid method (No. 3) or the the kinetic methods (Nos. 5,6 ) is lower than inulin clearance (tab. 1). The results explain why creatinine clearance findings, e.g. for rats, greatly differ between authors as compared with the standard method of inulin clearance $(2,12,13)$.

It is known that there are substances in serum which may negatively interfere with the peroxidase-coupled procedure as they potentially consume e. g. $\mathrm{H}_{2} \mathrm{O}_{2}$, or damage the activity of enzymes in the test reagent $(6$, $14)$. Our recovery studies exclude these possibilities, at least for rats. In addition, our creatinine values in sera of rats agree very well with values measured by high performance liquid chromatography (2). Therefore, we can be sure that the enzymatic procedure measures true creatinine concentrations.

This enzymatic method has advantages over other specific tests for creatinine determination. In comparison with enzymatic tests, which rely on changes of NADH (3), the peroxidase-coupled test is more sensitive and precise, requires short reaction time and is suitable for routine application $(6,14)$. Other specific methods, such as high performance liquid chromatography, are time-consuming, expensive and not generally available (15). Only $25 \mu \mathrm{l}$ of sample are sufficient for the micromethod used in this study. All other known methods, both enzymatic, picric acid and high performance liquid chromatography methods require higher sample volumes. The peroxidase-coupled test offers the advantage of repeated measurements of serum creatinine in small laboratory animals.

In summary, the test combination "Creatinine-PAP" can be recommended as a reliable, practical method for routine measurements of creatinine in laboratory animals.

\section{Acknowledgement}

We gratefully thank Ms. Silke Klotzek for skilful assistance. 


\section{References}

1. Narayanan, S. \& Appleton, H. D. (1980) Clin. Chem. 26, 1119-1126.

2. Meyer, M. H., Meyer Jr., R. A., Gray, R. W. \& Irwin, R. L. (1985) Anal. Biochem. 44, 285-290.

3. Szasz, G., Börner, U., Busch, E. W. \& Bablok, W. (1979) this J. 17, 683-687.

4. Apple, F., Bandt, C., Prosch, A., Erlandson, G., Holmstrom, V., Scholen, J. \& Googins, M. (1986) Clin. Chem. 32, 388-390.

5. Workshop Report "Creatinin PAP" Enzymatischer Test (1986) Boehringer Mannheim GmbH, Mannheim.

6. Guder, W. G., Hoffmann, G. E., Hubbuch, A., Poppe, W. A., Siedel, J. \& Price, C. P. (1986) this J. 24, 889-902.

7. Leathwood, P. D. \& Plummer, D. T. (1969) Enzymologia $37,240-250$.

8. Müller, H., Kluthe, R. \& Alexandropoulos, A. (1970) this J. 8, 394-397.
9. Arzneibuch der DDR, Diagnostische Laboratoriumsmethoden (1983), Akademie-Verlag, Berlin.

10. Davidson, W. D. \& Sackner, M. A. (1963) J. Lab. Clin Med. 62, 351-356.

11. Mitruka, B. M. \& Rawinsley, H. M. (1977) Clinical biochemical and hematological reference values in normal experimental animals. Masson, New York.

12. Goldman, R. (1967) Proc. Soc. Exp. Biol. Med. 125, $1021-1024$.

13. Harvey, A. M. \& Malvin, R. L. (1965) Am. J. Physiol. 209, $849-852$.

14. Goren, M. P., Osborne, S. \& Wright, R. K. (1986) Clin. Chem. 32, 548-551.

15. Holmes, E. W., Oeser, T. H., Kahn, S. E., Bekeris, L. \& Bermes Jr., E. W. (1983) Ann. Clin. Lab. Sci. 13, 503-511.

Dozent Dr. sc. K. Jung

Abteilung für

experimentelle Organtransplantationen

Bereich Medizin (Charité)

der Humboldt-Universität zu Berlin

Leninallee 49

DDR-1017 Berlin 
